\title{
Role of endogenous nitric oxide in the control of exocrine and endocrine pancreatic secretion in humans
}

\author{
J W Konturek, K Hengst, E Kulesza, A Gabryelewicz, S J Konturek, W Domschke
}

\begin{abstract}
Background-Nitric oxide (NO) is an unstable vasodilator formed by $\mathrm{NO}$ synthetase (NOS) from L-arginine (L-Arg) in various cells but its role in the control of pancreatic secretion in humans has not been examined. Aims-This study was designed to determine the role of endogenous $\mathrm{NO}$ in the control of exocrine and endocrine pancreas using NOS inhibitor, $\mathbf{N}^{\mathbf{G}}$-monomethylL-Arg (L-NMMA).

Methods-Pancreatic secretion was stimulated by intravenous infusion of secretin $(80 \mathrm{pmol} / \mathrm{kg} / \mathrm{h})$ plus caerulein $(50 \mathrm{pmol} / \mathrm{kg} / \mathrm{h})$ and duodenal content was aspirated by gastroduodenal tube. Two series of tests with secretagogue infusion were performed, one, with addition of graded doses of L-NMMA and, another, with addition of a constant dose of $L-A r g$ alone followed by L-NMMA alone and finally by a combination of $L-A r g$ and L-NMMA.
\end{abstract}

Results-Addition of L-NMMA in graded doses $(2-8 \mu \mathrm{mol} / \mathrm{kg} / \mathrm{h})$ reduced dose dependently the secretin-caerulein stimulated pancreatic enzyme secretion without alterations in the volume flow and bicarbonate outputs. The addition of L-Arg to L-NMMA reversed the inhibitory action of L-NMMA on protein enzyme response to secretin-caerulein in these subjects. Secretin-caerulein infusion caused significant increase in plasma insulin and pancreatic polypeptide levels but without changes in plasma glucagon or somatostatin levels. L-NMMA alone resulted in a significant fall in plasma insulin and pancreatic polypeptide levels, while L-Arg added to pancreatic secretagogue infusion caused a significant increase of plasma insulin and pancreatic polypeptide levels above those attained with secretagogues alone. After the addition of L-Arg to L-NMMA, both plasma insulin and pancreatic polypeptide levels rose significantly above the levels observed with L-NMMA plus secretin-CCK stimulation. Conclusion-This study provides evidence that the suppression of NOS reduces pancreatic enzyme secretion and the plasma insulin and pancreatic polypeptide levels suggesting that endogenous NO affects both exocrine and endocrine pancreatic secretion in humans.

(Gut 1997; 40: 86-91)

Keywords: pancreas, nitric oxide, L-NMMA, secretin, caerulein, insulin, pancreatic polypeptide.
Nitric oxide (NO), originally known as endothelium derived relaxing factor, ${ }^{1}$ is an unstable vasodilator released by endothelial cells ${ }^{2} 3$ and neurons ${ }^{45}$ to act as local hormone in the vicinity of these cells. It is formed from the terminal guanitidine nitrogen atom of $\mathrm{L}$-arginine (L-Arg) by constitutive NO synthetase (NOS) present in endothelial cells ${ }^{6}$ and neurons ${ }^{7}$ of various organs including gastrointestinal tract and the pancreas in various species including humans. ${ }^{89}$ The enzymatic synthesis of NO can be specifically inhibited by structural analogs of $\mathrm{L}$-Arg such as $\mathrm{N}^{\mathrm{G}}$-monomethyl-L-arginine (L-NMMA). ${ }^{10}$ The use of such L-arginine analogs helped in better understanding of the physiological action of NO. ${ }^{4}$

Recent studies performed in vivo and in vitro on various species including dogs, ${ }^{11}{ }^{12}$ pigs $^{13}$ and rats ${ }^{14}$ demonstrated that endogenous NO may be involved in neurally and hormonally mediated exocrine pancreatic secretion and in the function of pancreatic islets ${ }^{15}$ but no information is available regarding the possible involvement of $\mathrm{NO}$ in the control of exocrine and endocrine pancreatic secretion in humans.

This study was designed to use selective NOS inhibitor, L-NMMA, and the substrate of NOS, L-Arg, in healthy humans to evaluate the role of endogenous NO in the control of exocrine pancreatic secretion stimulated by secretin plus caerulein and of endocrine pancreatic islet hormones such as insulin glucagon, pancreatic polypeptide (PP), and somatostatin in healthy men.

\section{Methods}

Studies were conducted on two series (A and B), each including the same six healthy male volunteers (mean age 23 years, range 20-24; mean weight $74 \mathrm{~kg}$, range 67-80). Written informed consent was obtained from each subject, and the study was approved by the Human Review Committee.

All tests were performed after an overnight fast. The volunteers in both series swallowed a triple lumen tube. One tube was placed under fluoroscopic control in the upper duodenum adjacent to the papilla of Vater and used for continuous infusion of non-absorbable marker, polyethylene glycol, (PEG 4000, in saline); another lumen was positioned at the ligament of Treitz for continuous aspiration of duodenal content; and the third lumen was situated in the distal portion of the stomach for continuous aspiration of gastric acid to prevent this acid from entering the duodenum and disturbing the collection of the duodenal contents. 
Thereafter, the perfusion of PEG was started and the aspiration of duodenal contents was carried out for 30 minutes to determine basal pancreatic secretion. Then, intravenous (iv) infusion of secretin at a dose of $80 \mathrm{pmol} / \mathrm{kg} / \mathrm{h}$ plus caerulein $(50 \mathrm{pmol} / \mathrm{kg} / \mathrm{h})$ was started and continued for 180 minutes in series $\mathrm{A}$ and for 150 minutes in series $B$. After 60 minutes of secretagogue infusion in series $A$, when the secretory rate reached a well sustained plateau, the secretagogue infusion was either continued for a subsequent 180 minutes (control tests) or L-NMMA was added to iv infusion in gradually increasing doses $(2-8 \mu \mathrm{mol} / \mathrm{kg} / \mathrm{h})$, each dose being infused for 30 minutes and then doubled. During the last 30 minutes, the administration of L-NMMA was stopped and the infusion of secretin plus caerulein alone was continued. In series $B$, the pancreatic secretagogues were infused either alone throughout 150 minutes (control tests) or after initial 60 minute infusion, L-Arg $(1 \mathrm{mmol} / \mathrm{kg} / \mathrm{h}$ ) (for 30 minutes), then L-NMMA $(8 \mu \mathrm{mol} / \mathrm{kg} / \mathrm{h})$

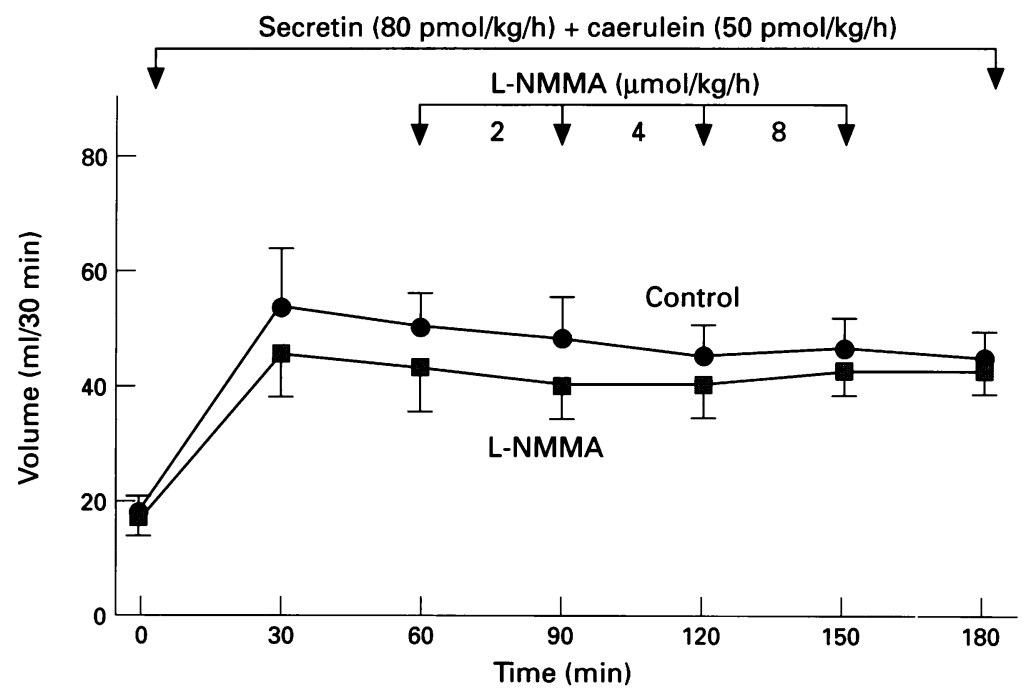

Figure 1: Pancreatic volume flow in response to secretin-caerulein stimulation without and with addition of L-NMMA in gradually increasing doses. Means (SEM) of six tests on six subjects.

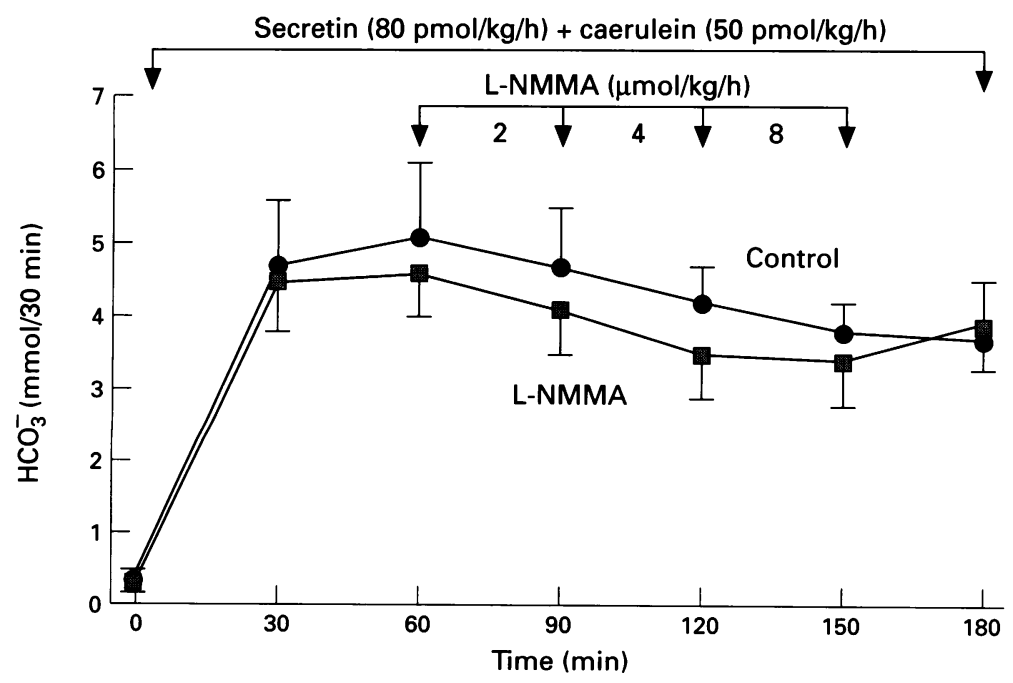

Figure 2: Pancreatic bicarbonate outputs in response to secretin-caerulein stimulation without and with addition of L-NMMA in gradually increasing doses. Means (SEM) of six tests on six subjects. (for another 30 minutes) and, finally, L-Arg combined with L-NMMA were given for final 30 minutes in the same doses.

Duodenal aspirates were collected on ice at 30 minute intervals. The volume of the duodenal aspirate was measured and the concentrations of bicarbonate, protein, and enzymatic activity (trypsin, chymotrypsin, amylase, and lipase) were determined with monotests (Boehringer, Mannheim, Germany). PEG concentration was determined turbidimetrically by the method of Hyden. ${ }^{10}$ The average amount of PEG recovered from the stomach was less than $5 \%$.

Blood samples were drawn from peripheral vein in series $B$ experiments at the end of 30 minutes of basal period and at the end of 30 minutes of iv infusion of secretin plus caerulein alone and at the end of 30 minutes infusion of these secretagogues plus L-Arg then L-NMMA and finally combination of L-Arg L-NMMA for measurements of plasma immunoreactive gastrin, insulin, glucagon, PP and somatostatin. Plasma was separated from ethylene-diaminetetraacetic acid (EDTA)anticoagulated blood and stored at $-20^{\circ} \mathrm{C}$ for radioimmunoassays using techniques described previously. ${ }^{16-20}$

Pulse rate, mean arterial blood pressure, and subjective symptoms were monitored throughout the administration of L-NMMA.

Basal and secretagogue induced duodenal volume and secretory outputs of bicarbonate, protein, and enzymes were determined. These outputs were corrected by PEG recovery and the infusion rate of PEG was subtracted from that recovered from the duodenum.

All results are expressed as means (SEM). The significance of the differences between the control secretory outputs or plasma hormone concentrations and those obtained with administration of L-NMMA was evaluated by Student's test for paired samples. Statistical significance was set at the $5 \%$ level.

\section{Results}

Secretin plus caerulein infused iv in a constant dose induced in series A experiments a well sustained pancreatic volume flow and bicarbonate outputs (Figs 1 and 2). In control tests with secretagogues alone, the peak volume and bicarbonate outputs were obtained after about 30-60 minutes of secretagogue infusion reaching, respectively, about $53(12) \mathrm{ml} / 30 \mathrm{~min}$ and $5 \cdot 1(1 \cdot 0) \mathrm{mmol} / 30 \mathrm{~min}$, respectively. These secretory peaks were followed by a relatively well sustained secretory plateau throughout the period of infusion. Addition of L-NMMA in gradually increasing doses to iv infusion of pancreatic secretagogues did not change significantly the volume flow and bicarbonate outputs at any dose used.

In contrast, the protein outputs, which in control tests reached the peak (about $69(8) \mathrm{mg} /$ $30 \mathrm{~min}$ ) also during the first 30 minute period and then tended to decline for the rest of experiment, was considerably and dose dependently reduced by the addition of L-NMMA falling at $8 \mu \mathrm{mol} / \mathrm{kg} / \mathrm{h}$ to about $20 \%$ of 
the control level. Upon the withdrawal of L-NMMA infusion the protein outputs tended to increase but failed to reach the control values within a 30 minute period (Fig 3 ).

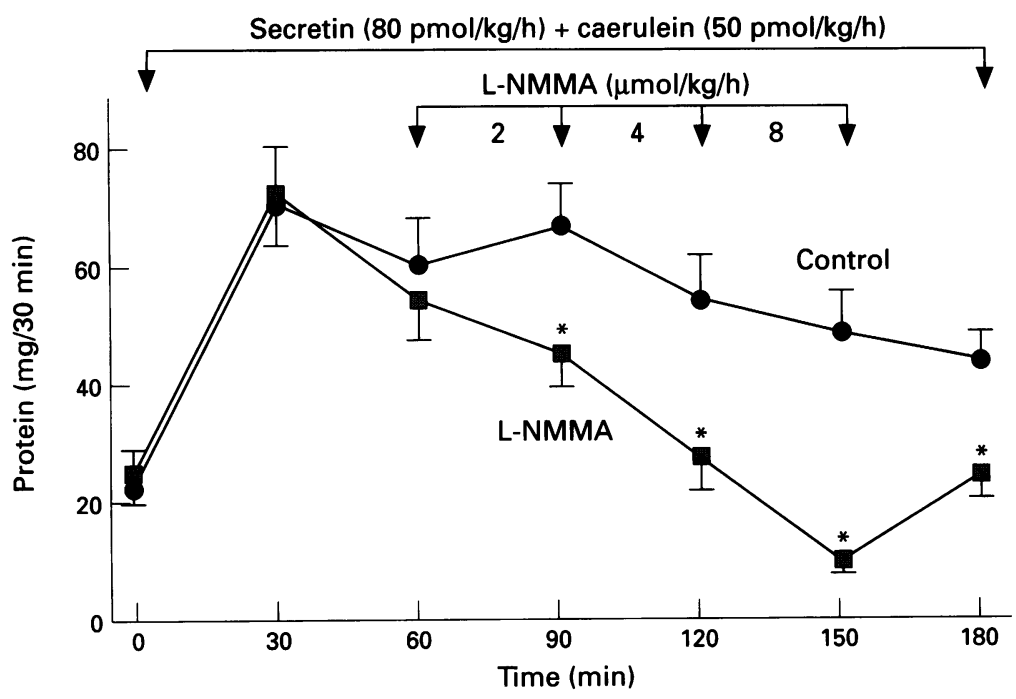

Figure 3: Pancreatic protein outputs in response to secretin-caerulein stimulation without and with addition of L-NMMA in gradually increasing doses. Means (SEM) of six tests on six subjects. ${ }^{\star}$ Shows significant decrease below the control values obtained with secretincaerulein alone.

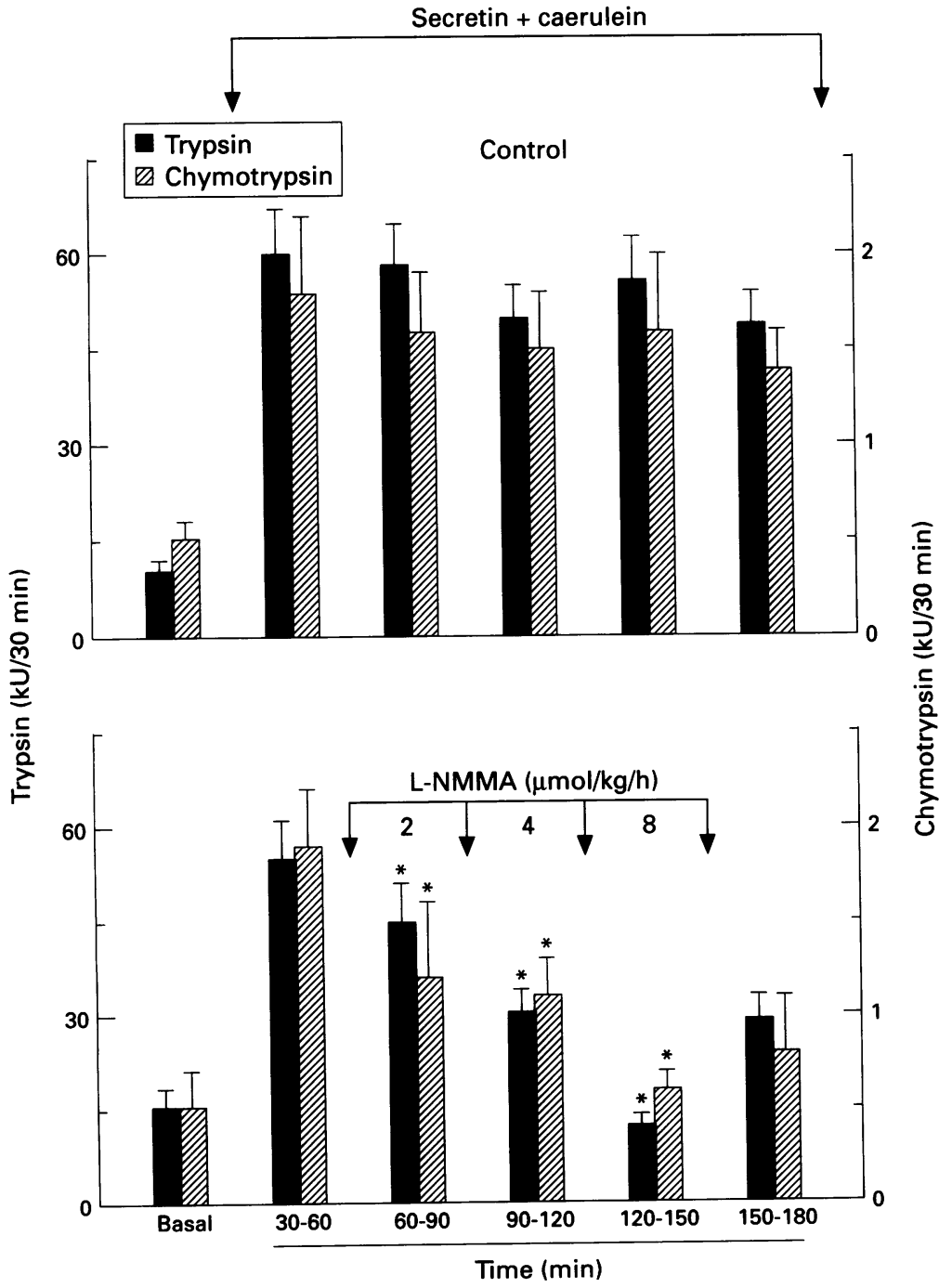

Figure 4: Pancreatic trypsin and chymotrypsin outputs in response to secretin-caerulein stimulation without (upper panel) and with addition of L-NMMA in gradually increasing doses (lower panel) and with addition of L-NMMA in gradually increasing doses (lower panel). Means (SEM) of six tests on six subjects. *Shows significant decrease below the control values obtained with secretin-caerulein alone.
Figs 4 and 5 show the pancreatic enzyme secretion in response to secretin plus caerulein alone (upper panel) and after addition of graded doses of L-NMMA to secretagogue infusion (lower panel) and after addition of graded doses of L-NMMA to secretagogue infusion (lower panel). In control tests with secretagogues alone, the enzyme outputs were relatively well sustained but the addition of L-NMMA resulted in almost complete suppression (at $8 \mu \mathrm{mol} / \mathrm{kg} / \mathrm{h}$ ) of trypsin and chymotrypsin and partial reduction in amylase and lipase secretion in these subjects.

In tests of series $B$, the volume flow and bicarbonate outputs also reached the peaks during initial 30-60 minutes of iv infusion of secretin plus caerulein. The addition to iv infusion of L-Arg $(1 \mathrm{mmol} / \mathrm{kg} / \mathrm{h})$, followed by L-NMMA ( $8 \mu \mathrm{mol} / \mathrm{kg} / \mathrm{h}$ ) and, finally, by the combination of L-Arg plus L-NMMA (in the same doses) did not affect significantly the pancreatic volume and bicarbonate outputs (Table I). In contrast, the protein secretion, which showed significant $(\mathrm{p}<0.05)$ increase during L-Arg administration, was significantly $(p<0.05)$ reduced by L-NMMA and this reduction was partly (but significantly) reversed by the addition of L-Arg to L-NMMA (Table I).

With the addition of L-Arg alone to secretagogue infusion, the pancreatic enzyme outputs tended to increase but this did not reach statistical significance. When L-NMMA alone was added to secretin-caerulein infusion, a marked and significant $(p<0.05)$ fall in pancreatic enzyme outputs below the control values obtained with secretagogues alone was observed (Table II). With the combination of L-Arg and L-NMMA, the enzyme response to secretin-caerulein showed a significant $(p<0.05)$ rise above the value obtained with infusion of L-NMMA alone in these subjects.

Basal plasma concentrations of insulin, glucagon, $\mathrm{PP}$, and somatostatin averaged 10.5 $(2 \cdot 4) \mu \mathrm{U} / \mathrm{ml}, 45 \cdot 3(5 \cdot 2) \mathrm{pM} / 1,18 \cdot 1$ (2.3) $\mathrm{pM} /$, and $4 \cdot 2(0 \cdot 6) \mathrm{pM} /$, respectively. Infusion of secretin plus caerulein caused significant $(p<0.05)$ increments in plasma insulin and PP values. Plasma glucagon and somatostatin were unchanged by secretagogue infusion. Administration of L-Arg alone significantly $(p<0.05)$ raised plasma insulin by $75 \%$, glucagon by $44 \%$, and PP by $80 \%$, while plasma somatostatin remained unchanged. Addition of L-NMMA alone at $8 \mu \mathrm{mol} / \mathrm{kg} / \mathrm{h}$ reduced significantly $(p<0.05)$ the secretagogue induced increments in plasma insulin and PP by about $25 \%$ and $30 \%$, respectively. Plasma glucagon remained unchanged while plasma somatostatin tended to increase but this was not statistically significant. When L-Arg was combined with L-NMMA, the plasma hormone changes caused by L-NMMA alone were partially reversed (Table III).

The pulse rate and the mean arterial blood pressure did not show significant alterations throughout the experimentation with secretin plus caerulein infusion in tests without L-NMMA. In tests with the administration of L-NMMA at lower dose, no changes were 


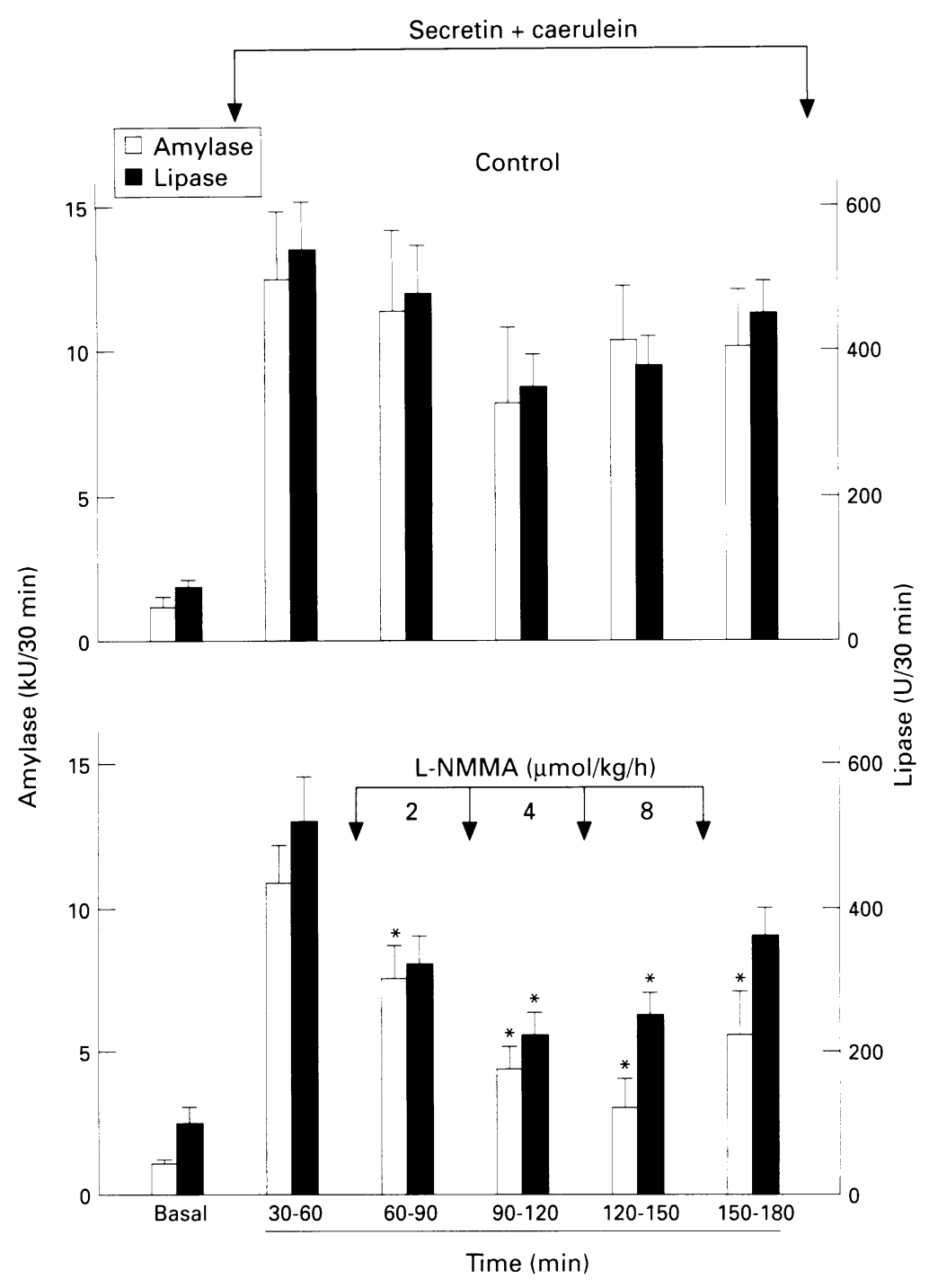

Figure 5: Pancreatic amylase and lipase outputs in response to secretin-caerulein stimulation without (upper panel) and with addition of L-NMMA in gradually increasing doses (lower panel). Means (SEM) of six tests on six subjects. ${ }^{\star}$ Shows significant decrease below the control values obtained with secretin-caerulein alone.

noticed but at the highest dose $(8 \mu \mathrm{mol} / \mathrm{kg} / \mathrm{h})$, the mean arterial blood pressure increased significantly $(\mathrm{p}<0.05)$ by about $20 \mathrm{~mm} \mathrm{Hg}$ over the value recorded before L-NMMA administration (Table IV).

No subjective side effects during secretagogue infusion without or with addition of L-NMMA and/or L-Arg were recorded in these subjects.

\section{Discussion}

This study provides evidence that the suppression of constitutive NOS by L-NMMA in humans results in a marked reduction in pancreatic protein enzyme secretion and that this reduction is accompanied by a significant decrease in plasma insulin and PP. These effects are specific because the addition of L-Arg, a substrate of NOS, significantly attenuated the reduction in pancreatic enzyme and plasma hormone levels caused by L-NMMA.

This is the first report on the influence of the suppression of the biosynthesis of endogenous $\mathrm{NO}$ on exocrine and endocrine pancreatic secretion in humans. Previous studies in dogs, ${ }^{11}{ }^{12}$ pigs, ${ }^{13}$ and rats ${ }^{9} 1415$ showed that the suppression of constitutive NOS by L-nitroarginine derivatives resulted in the inhibition of neural, hormonal, and postprandial exocrine pancreatic secretion. This inhibition was accompanied by the reduction in the release of gastrin and cholecystokinin in vivo ${ }^{11}$ and of insulin release in vitro. ${ }^{21}{ }^{22}$ It is of interest that, unlike in dogs, ${ }^{11}{ }^{12}$ pigs $^{13}$ or rats, ${ }^{14}$ L-NMMA in humans failed to affect water and bicarbonate secretion, but similarly as in animals it caused a marked inhibition of protein enzyme secretion.

The fact that L-nitro-arginines caused a significant reduction in amylase release by dispersed canine or rat pancreatic acini stimulated by cholecystokinin ${ }^{11}$ and amylase secretion by rat acinar cells stimulated by carbacho $1^{15}$ suggests that endogenous NO may be involved in the mechanism of enzyme secretion by acinar cells. On the other hand, the finding that L-NMMA attenuated the pancreatic blood flow both in resting and hormonally stimulated pancreas in $\operatorname{dogs}^{11}$ and rats $^{14}$ and that this effect could be reversed by the addition of L-Arg (but not D-Arg) to L-NMMA suggests that endogenous NO may affect the pancreatic secretion, at least in part, through the changes in vascular bed.

Both direct effects on acinar cells and its indirect influence on pancreatic secretion through pancreatic blood flow are in keeping with the findings that NOS can be visualised by immunocytochemistry using specific antibodies against NOS and by histochemistry using nicotiamide adenine dinucleotide hydrogen phosphate-diaphorase (NADPH-d) as a

TABLE I Pancreatic volume flow, $\mathrm{HCO}_{3}{ }_{3}$, and protein outputs in tests without or with the addition of L-Arg alone (1 mmol/kg/h), L-NMMA alone ( $8 \mu \mathrm{mol} / \mathrm{kg} / \mathrm{h})$, and L-Arg plus L-NMMA during iv infusion of secretin plus caerulein. Mean (SEM) of six tests on six subjects of series $B$

\begin{tabular}{|c|c|c|c|c|}
\hline Test & $\begin{array}{l}\text { Time } \\
\text { (min) }\end{array}$ & $\begin{array}{l}\text { Volume } \\
(\mathrm{mL} / 30 \mathrm{~min})\end{array}$ & $\begin{array}{l}\mathrm{HCO}_{3} \\
(\mathrm{mmol} / 30 \mathrm{~min})\end{array}$ & $\begin{array}{l}\text { Protein } \\
(\mathrm{mg} / 30 \mathrm{~min})\end{array}$ \\
\hline \multirow[t]{5}{*}{ Secretin+caerulein alone (control) } & $0-30$ & $57(5)$ & $5 \cdot 1(1 \cdot 6)$ & $62(8)$ \\
\hline & $30-60$ & $56(8)$ & $5 \cdot 6(1 \cdot 2)$ & $75(12)$ \\
\hline & $60-90$ & $52(6)$ & $4.8(0.8)$ & $64(9)$ \\
\hline & $90-120$ & $48(7)$ & $4 \cdot 2(1 \cdot 0)$ & $58(10)$ \\
\hline & $120-150$ & $42(6)$ & $3.8(0.9)$ & $49(8)$ \\
\hline \multirow[t]{5}{*}{ Secretin+caerulein $+\mathrm{L}-\mathrm{Arg}+\mathrm{L}-\mathrm{NMMA}+\mathrm{L}-\mathrm{Arg}+\mathrm{L}-\mathrm{NMMA}$} & 0-30 & $60(12)$ & $4 \cdot 2(1 \cdot 3)$ & $76(12)$ \\
\hline & $30-60$ & $58(10)$ & $5 \cdot 3(1 \cdot 4)$ & $72(6)$ \\
\hline & $60-90 \ddagger$ & $62(12)$ & $5 \cdot 6(1 \cdot 2)$ & $84(7)^{\star}$ \\
\hline & $90-120 s$ & $47(11)$ & $4 \cdot 2(1 \cdot 6)$ & $18(4)^{\star}$ \\
\hline & $120-150$ & $50(14)$ & $4.5(1.5)$ & $39(6) \dagger$ \\
\hline
\end{tabular}

* Significant $(p<0.05)$ change compared with the value obtained with secretin plus caerulein. + Significant $(p<0 \cdot 05)$ increase above the value obtained with L-NMMA. $\ddagger$ Period when L-Arg alone was added to iv infusion; §period when L-NMMA alone was added to iv infusion; $\uparrow$ period when L-Arg was added to L-NMMA infusion. 
TABLE II Pancreatic enzyme outputs in response to secretin plus caerulein infusion in tests of series $B$ without or with the addition of $L-A r g$ alone $(1 \mathrm{mmol} / \mathrm{kg} / \mathrm{h}), L-N M M A$ alone $(8 \mu \mathrm{mol} / \mathrm{kg} / \mathrm{h})$, and $L-A r g$ plus $L-N M M A$. Mean (SEM) of six tests on six subjects of series $B$

\begin{tabular}{|c|c|c|c|c|c|}
\hline Test & $\begin{array}{l}\text { Time } \\
\text { (min) }\end{array}$ & $\begin{array}{l}\text { Trypsin } \\
(K U / 30 \mathrm{~min})\end{array}$ & $\begin{array}{l}\text { Chymotrypsin } \\
(K U / 30 \mathrm{~min})\end{array}$ & $\begin{array}{l}\text { Amylase } \\
(K U / 30 \mathrm{~min})\end{array}$ & $\begin{array}{l}\text { Lipase } \\
\text { (U/30 min) }\end{array}$ \\
\hline Secretin+caerulein alone & $\begin{array}{c}0-30 \\
30-60 \\
60-90 \\
90-120 \\
120-150 \\
0-30 \\
30-60 \\
60-90 \ddagger \\
90-120 \$ \\
120-1509\end{array}$ & $\begin{array}{l}65(7) \\
58(12) \\
52(8) \\
56(10) \\
49(7) \\
60(12) \\
58(10) \\
62(12) \\
47(11) \\
50(14)\end{array}$ & $\begin{array}{l}1.8(0.6) \\
2.0(0.5) \\
1.9(0.3) \\
1.7(0.4) \\
1.8(0.4) \\
4.2(1.3) \\
5.3(1.4) \\
5.6(1.2) \\
4.2(1.6) \\
4.5(1.5)\end{array}$ & $\begin{array}{c}14(3) \\
15(4) \\
12(2) \\
12(2) \\
10(1) \\
18(4) \\
17(3) \\
24(5) \\
7(2)^{\star} \\
14(3) \dagger\end{array}$ & $\begin{array}{l}642(75) \\
660(58) \\
620(48) \\
570(64) \\
510(50) \\
617(80) \\
680(94) \\
724(62) \\
230(42)^{\star} \\
468(50) \dagger\end{array}$ \\
\hline
\end{tabular}

*Significant $(p<0.05)$ decrease below the control value obtained with secretin plus caerulein alone. $\nmid$ Significant $(p<0.05)$ increase above the value obtained with L-NMMA alone. ¥Period when L-Arg alone was added to iv infusion; \period when L-NMMA alone was added to iv infusion; ๆperiod when L-Arg plus L-NMMA was added to iv infusion.

marker for NOS in acinar cells, blood vessels, and intrapancreatic neurons. ${ }^{6-9}$ The fact that NOS is colocalised in the intrapancreatic ganglia $^{69}$ with vasoactive intestinal peptides suggests that the attenuation of pancreatic blood flow by inhibitors of NOS ${ }^{114}$ could originate from the removal of the interaction of endogenous $\mathrm{NO}$ and vasoactive intestinal peptides on pancreatic circulation. ${ }^{23}$

As shown in this study on humans, the suppression of NOS by L-NMMA resulted in the reduction in secretagogue stimulated increment in plasma insulin and PP levels. As these effects were reversed by the addition of L-Arg to L-NMMA, the results could be interpreted that endogenous $\mathrm{NO}$ in humans contributes to the release of insulin and PP and remains in agreement with previous reports demonstrating the presence of NOS in varicose nerve terminals within the pancreatic islets and in the islet cell itself. $^{67}$

The mechanisms of exocrine and endocrine pancreatic secretion involve a variety of neurohormonal factors among which non-adrenergic

TABLE III Plasma concentrations of insulin, glucagon, PP, and somatostatin under basal conditions and during iv infusion of secretin plus caerulein alone (control) and with the addition of $L-A r g, L-N M M A$, and $L-A r g$ plus $L-N M M A$. Means (SEM) of six tests on six subjects of series $B$

\begin{tabular}{lllll}
\hline Test & $\begin{array}{l}\text { Insulin } \\
(\mu U / m l)\end{array}$ & $\begin{array}{l}\text { Glucagon } \\
(p M / l)\end{array}$ & $\begin{array}{l}P P \\
(p M / l)\end{array}$ & $\begin{array}{l}\text { Somatostatin } \\
(p M / l)\end{array}$ \\
\hline Basal & $10 \cdot 5(2 \cdot 4)$ & $45 \cdot 3(5 \cdot 2)$ & $18 \cdot 1(2 \cdot 3)$ & $4 \cdot 2(0 \cdot 6)$ \\
Secretin+caerulein alone (control) & $16 \cdot 5(2 \cdot 9)$ & $47 \cdot 4(4 \cdot 9)$ & $53 \cdot 7(5 \cdot 8)$ & $4 \cdot 7(0 \cdot 5)$ \\
+L-Arg (1 mmol/kg h) & $28 \cdot 2(3 \cdot 3)^{\star}$ & $68 \cdot 2(7 \cdot 1)^{\star}$ & $96 \cdot 5(7 \cdot 4)^{\star}$ & $5 \cdot 6(1 \cdot 4)$ \\
+L-NMMA (8 $\mu \mathrm{mol} / \mathrm{kg} \mathrm{h})$ & $12 \cdot 4(1 \cdot 1) \dagger$ & $49 \cdot 5(6 \cdot 2)$ & $37 \cdot 1(3 \cdot 0) \dagger$ & $6 \cdot 1(0 \cdot 4)$ \\
+L-ARG+L-NMMA & $21 \cdot 2(2 \cdot 3) \ddagger$ & $51 \cdot 3(7 \cdot 1)$ & $64 \cdot 5(9 \cdot 2) \ddagger$ & $4 \cdot 9(1 \cdot 2)$ \\
\hline
\end{tabular}

*Significant $(p<0.05)$ increase compared with the control values obtained with secretin plus caerulein. +Significant $(p<0.05)$ decrease below the control value obtained with secretin plus caerulein. ISignificant change compared with the values obtained with L-NMMA.

TABLE IV Mean arterial blood pressure and pulse rate during iv infusion of secretin plus caerulein without (control) and with addition of graded doses of $L-N M M A$ as well as with the addition of $L-A r g, L-N M M A$ or their combination to pancreatic secretagogues. Mean (SEM) of six tests on six subjects in tests of series $A$ and $B$

\begin{tabular}{lcl}
\hline Test & $\begin{array}{c}\text { Mean arterial blood pressure } \\
(\mathrm{mm} \mathrm{Hg})\end{array}$ & $\begin{array}{c}\text { Pulse rate } \\
\text { (beats/min) }\end{array}$ \\
\hline Basal & $94(12)$ & $78(6)$ \\
Secretin+caerulein alone (control) & $89(10)$ & $84(10)$ \\
L-NMMA 2 $\mu \mathrm{mol} / \mathrm{kg} \mathrm{h}$ & $98(10)$ & $82(9)$ \\
L-NMMA $4 \mathrm{~mol} / \mathrm{kg} \mathrm{h}$ & $108(12)$ & $80(12)$ \\
L-NMMA $8 \mu \mathrm{mol} / \mathrm{kg} \mathrm{h}$ & $121(10)^{\star}$ & $76(14)$ \\
L-Arg $1 \mathrm{mmol} / \mathrm{kg} \mathrm{h}$ & $85(17)$ & $74(12)$ \\
L-Arg $1 \mathrm{mmol} / \mathrm{kg} \mathrm{h}$ h-NMMA $8 \mu \mathrm{mol} / \mathrm{kg} \mathrm{h}$ & $102(14)$ & $78(10)$ \\
\hline
\end{tabular}

$\star$ Significant $(p<0.05)$ change compared with the control values recorded during secretin caerulein infusion alone. non-cholinergic (NANC) neurons have been implicated. ${ }^{4}{ }^{24}$ Because NO has been shown to be one of the mediators in some NANC nerves, vascular epithelium and acinar cells, it is probable that it might also plays some part in the physiological control of pancreatic secretion.

As inducible NOS activated by inflammatory mediators may release large quantities of NO in acute pancreatitis, it may contribute to the pancreatic cell cytotoxicity, excessive peripheral vasodilatation, and marked hypotension observed in this disease. ${ }^{25}$ Further studies are needed to determine the role of NO in the pathogenesis of acute pancreatitis and accompanied alterations in systemic and pancreatic circulation and pancreatic secretion as well as the possible usefullness of NOS inhibitors in the control of endotoxic shock in the course of this disease.

1 Furchgott RF, Zawadzki JV. The obligatory role of ndothelial cells in relaxation of arterial smooth muscle by acetylcholine. Nature 1980; 288: 373-6.

2 Palmer RMJ, Ferridge AG, Moncada S. Nitric oxide release accounts for the biological activity of endotheliumderived relaxing factor. Nature 1987; 327: 524-6.

3 Ignarro LJ, Buga GM, Wood KS, Byrns RE, Chaudhuri G. Endothelium derived relaxing factor produced and released from artery and vein in nitric oxide. Proc Nat Acad Sci USA 1987; 84: 9265-9.

4 Konturek SJ, Konturek PCH. Role of nitric oxide in the digestive system. Digestion 1995; 56: 1-13.

5 Dembinska-Kiec A, Goscinski I, Szczudlik. Labile products of vascular endothelium as mediators and modulators of the functions of the central nervous system. $\exists$ Physiol the functions of the central

6 Ekblad E, Alm P, Sundler F. Distribution, origin and projections of nitric oxide synthase-containing neurons in the gut and pancreas. Neuroscience 1994; 63: 233-48.

7 Liu HP, Leong SK, Tay SS. Localization of NADPHdiaphorase positive neurons in the pancreas of the mouse, rat, chick, kitten and monkey. $\mathcal{F}$ Hirnforsch 1994; 35 : 501-10.

8 Bouvens L, Kloppel G. Cytochemical localization of NADPH-diaphorase in the four types of pancreatic islet cells. Histochemistry 1994; 101: 209-14.

9 Kirchgessner AL, Liu MT, Gershon MD. NADPH diaphorase (nitric oxide synthase)-containing nerves in the enteropancreatic innervation: sources, co-stored neuropeptides and pancreatic function. $f$ Comp Neurol 1994; 342: 115-30.

10 Hyden S. A turbidimetric method for the determination of higher polyethylene glycols in biological materials. Kungl Lantbrukshogsk Ann 1956; 22: 139-45.

11 Konturek SJ, Bilski J, Konturek PK, Cieszkowski M, Pawlik W. Role of endogenous nitric oxide in the Pawlik W. Role of endogenous nitric oxide in the control of canine pancreatic secretion

12 Maczka M, Thor P, Bilski J, Konturek SJ. Nitric oxide and the interaction between motility and pancreatic secretion.

13 Holst J, Rasmussen TN, Schmidt P. Role of nitric oxide in neurally induced pancreatic exocrine secretion in pigs. Am $\mathcal{F}$ Physiol 1994; 266: 206-13.

14 Konturek SJ, Szlachcic A, Dembinski A, Warzecha Z, Jaworek J, Stachura J. Nitric oxide in pancreatic secretion and hormone-induced pancreatic in rats. Int $\mathcal{F}$ Pancreatol 1994; 15: 19-28. 
15 Wrenn RW, Currie NG, Herman LE Nitric oxide participates in the regulation of pancreatic secretion. Life Sci 1994; 55: 511-8.

16 Konturek SJ, Swierczek J, Kwiecien N, Obtutowicz W, Dobrzanska M, Kopp B, et al. Gastric secretory and plasma hormonal responses to sham-feeding of varying duration in patients with duodenal ulcer. Gut 1981; 22: 1003-10.

17 Morgan CR, Lazarow AL. Immunoassay of insulin: two antibody system. Diabetes $1963 ; 12: 115-26$.

18 Kokot F, Kuska J. Method of radioimmunoassay of insulin. Przegl Lek 1974; 30: 902-9.

19 Harris V, Falooma GR, Unger RH. Glucagon. In: Jaffe BM, Behrman XX, eds. Methods of hormone radioimmunoassay. 2nd ed. New York: Academic Press, 1979: 643.

20 Konturek JW, Stoll R. Gutwinska-Konturek M, Konturek SJ, Domschke W. Cholecystokinin in the regulation of gastric acid and endocrine pancreatic secretion in humans. Scand $\mathcal{f}$ Gastroenterol 1993; 28: $40-40$.
21 Schmidt $\mathrm{HH}$, Warner TD, Ishii $\mathrm{K}$, Sheng $\mathrm{H}$, Murad F. Insulin secretion from pancreatic $B$ cells caused by Insulin secretion from pancreatic B cells caused by L-arginin

22 Jones PM, Persaud SJ, Bjaaland T, Pearson ID, Howell SL. Nitric oxide is not involved in the initiation of insulin secretion from rat islets of Langerhans. Diabetologia 1992; 35: 1020-7.

23 Shimosegawa T, Abe T, Satoh A, Abe R, Kikuchi Y, Koizumi M, Toyota T. NADHP-diaphorase activity in neurons of the mammalian pancreas: coexpression with vasoactive intestinal peptide. Gastroenterology 1993; 105: 999-1008.

24 Solomon TE. Control of exocrine pancreatic secretion. In: Physiology of the gastrointestinal tract. New York: Raven Physiology of the gastrointestinal tract. New York. Raven

25 Knowles RG, Satter M, Brooks SL, Moncada S. Antiinflammatory glucocorticoids inhibit induction by endotoxin of nitric oxide synthase in the lung, liver and aorta of the rats. Biochem Biophys Res Commun 1990; 172: 1042-8. 